\title{
What to Know About Travel Related Infections
}

\section{Seyahat Ilişkili Enfeksiyonlarda Akılda Tutulması Gerekenler}

\author{
(D) Fatmanur PEPE, (D) Esragül AKINCI, (D) Hürrem BODUR \\ University of Health Sciences, Ankara Numune Health Practice and Research, Clinic of Infectious Diseases and Clinical Microbiology, \\ Ankara, Turkey
}

\section{Abstract}

Travel is as old as human history. People travel for purposes such as migration, commerce, education, missionary activity, and entertainment. Historically, these human movements gave rise to geographical discoveries, trade, and economic development. Distances that took months to traverse by horseback can now be traveled in a matter of hours. The world has become a village inhabited by seven billion people, 1.2 billion of whom are tourists. Although the distance between Africa and America is $14,000 \mathrm{~km}$ and 20 hours by plane, there were also cases in the United States during the Ebola epidemic in Africa. Infectious agents have reached beyond the geographies where they are considered endemic. This review was written to highlight the change in infectious agents which are not common in Turkey and are imported by tourists, and to provide an overview of travel-related infections. In addition, infections with high mortality and morbidity, such as malaria, dengue, enteric fever, hepatitis, leptospirosis, and gastroenteritis, are described in more detail.

Keywords: Travel related infection, tropical disease

\section{Öz}

Seyahatler insanlık tarihi kadar eskidir. İnsanlar göç, ticaret, eğitim, misyonerlik ve eğlence gibi amaçlarla seyahat etmektedir. Bu insan hareketleri tarih boyunca coğrafi keşiflere, ticari ve ekonomik gelişmelere neden olmuştur. At sırtında aylarca sürecek mesafeler saatler içinde geçilir hale gelmiştir. Dünya, turist sayısının 1,2 milyarı bulduğu ve yedi milyar insanın yaşadığı bir köye dönüşmüştür. Afrika Amerika kıtaları arası mesafe uçakla 14 bin kilometre ve 20 saat sürmesine rağmen Afrika'daki Ebola virüs salgınında, Amerika Birleşik Devletleri'nde de hastalar görülmüştür. Enfeksiyon kaynaklı etkenler endemik olarak görüldüğü coğrafyaların dışına ulaşmıştır. Bu derleme, Türkiye'de sık görülmeyen, turistlerle taşınan enfeksiyon etkenlerindeki değişime dikkat çekmek ve seyahat enfeksiyonlarını gözden geçirmek amacıyla yazılmıştır. Ayrıca mortalitesi ve morbiditesi yüksek olan sıtma, deng, enterik ateş, hepatit, leptospiroz, gastroenteritler gibi enfeksiyonlara daha ayrıntılı yer verilmiştir.

Anahtar Kelimeler: Seyahat ilişkili enfeksiyon, tropikal hastalık

\section{Introduction}

International travel has increased as a result of social development, advances in information and communication technologies, and improved life standards. Reports from the World Tourism Organization indicate that the global number of international tourists reached 1.2 billion in 2015, an increase of $4.6 \%$ from the previous year ${ }^{[1]}$. Tourism is also growing steadily in Turkey. According to the Turkish Statistical Institute, the number of passengers using airports for international departures reached 71 million in $2016^{[2]}$.

Increases in tourism also bring increases in travel-related diseases. Depending on the destination, 22-64\% of tourists experience health problems ${ }^{[3]}$. Most of the conditions associated with infection are self-limiting diseases such as diarrhea and respiratory and skin infections ${ }^{[4,5]}$. Less than $1 \%$ of patients require hospitalization ${ }^{[6]}$. Noninfectious health problems that may occur during travel include car sickness, jet lag, venous thrombosis,

Cite this article as: Pepe F, Akıncı E, Bodur H. What to Know About Travel Related Infections. Mediterr J Infect Microb Antimicrob 2018;7:1.

Address for Correspondence/Yazışma Adresi: Fatmanur Pepe MD, University of Health Sciences, Ankara

Numune Health Practice and Research, Clinic of Infectious Diseases and Clinical Microbiology, Ankara, Turkey

Phone: +90 5336810186 E-mail: fatmanurpepe@gmail.com

Received/Geliş Tarihi: 30.06.2017 Accepted/Kabul Tarihi: 05.01.2018 ORCID ID: orcid.org/0000-0002-3975-7321

${ }^{\circ}$ Copyright 2018 by the Infectious Diseases and Clinical Microbiology Specialty Society of Turkey

Mediterranean Journal of Infection, Microbes and Antimicrobials published by Galenos Yayinevi. 
embolism, sunburn, sunstroke, insect bite/sting, animal bite, poisoning, drowning, injuries, and traffic accidents ${ }^{[7]}$. The rate of travel-related mortality is $0.001 \%$, with only $1 \%$ of those cases being infectious in origin ${ }^{[3,4]}$. Cardiovascular problems and traffic accidents are the most common causes of mortality ${ }^{[3]}$.

Surveillance systems and organizations exist to determine the epidemiological characteristics of destination countries and provide guidance to doctors and travelers ${ }^{[8-14]}$. The travel-related health authority in Turkey is the Directorate General of Health Services for Borders and Coasts. There are 43 Travel Health Centers (THCs) in Turkey to provide medical advice to tourists planning to travel abroad. In cities without a THC, doctors should choose the nearest THC using the website of the Ministry of Health, the Directorate General of Health Services for Borders and Coasts of Turkey and refer tourists to these centers at least 4-6 weeks before their trip ${ }^{[15]}$.

Many of the life-threatening travel-related infections (TRIs) are preventable and can be treated when diagnosed early ${ }^{[16]}$. Obtaining medical advice before travel and receiving appropriately timed vaccinations reduces the risk of many TRIs. However, 20-80\% of travelers do not seek pretravel health consultation due to lack of awareness ${ }^{[17-19]}$. In a Turkish study by Selcuk et al. ${ }^{[20]}$ on individuals traveling to Africa for business, it was found that $91 \%$ of the tourists obtained information from a $\mathrm{THC}$ before traveling. Despite this high rate of consultation, they determined that the timing of presentation was inappropriate and too late.

The Centers for Diseases Control and Prevention, USA (CDC) suggests that tourists entering Turkey review the routine vaccination schedule, complete any missing hepatitis $A$ and $B$ vaccinations, and to be vaccinated for typhoid if planning to go to rural areas and visit relatives ${ }^{[21]}$.

With this review, we sought to highlight changes in the infectious agents which are uncommon in Turkey and usually carried by tourists, and to review TRIs. Diseases with high mortality and morbidity, such as malaria, dengue fever, enteric fever, hepatitis, leptospirosis, and gastroenteritis, are discussed in more detail.

\section{Pretravel Precautions to Protect Against Infection}

Individuals planning to travel should consult a primary care physician/THC 4-6 weeks before their trip. The physician should do the following at their first pretravel visit:

1. Perform an individualized risk assessment for tourists;

- Medical history (regular medicines, systemic diseases, vaccinations, previous surgeries, pregnancy and breastfeeding, allergies),

- Destination and season of travel,
- Planned activities (trekking, water sports, safari, etc.),

- Type of accommodation,

- Duration and purpose of trave[ ${ }^{[7]}$.

2. Evaluate need for prophylaxis/treatment;

- Review the routine vaccination history (measles, pneumococcus, etc.),

- Plan region-specific travel vaccinations (yellow fever, rabies, Japanese encephalitis),

- Administer malaria prophylaxis in case of risk,

- Explain preventive measures for traveler's diarrhea and prescribe loperamide and antibiotics for self-treatment ${ }^{[7]}$.

3. Educate travelers about what they can do to prevent disease;

a) Give information about vectorborne diseases and prevention methods.

In areas of risk, necessary precautions for protection against arthropod-borne diseases such as malaria, rickettsial diseases, dengue, leishmaniasis, filariasis, Chikungunya, and zika virus include:

- Wearing seasonal clothes that cover the entire body,

- Applying insect repellent ( $\mathrm{N}, \mathrm{N}$-diethyl-meta-toluamide) (DEET 30-35\%) to exposed body parts every 4-6 hours,

- Using permethrin-impregnated bednet and clothing in areas with high risk of malaria or Japanese encephalitis,

- Checking the entire body at least once a day in areas with risk of tick-borne diseases ${ }^{[7]}$.

b) Provide information about other travel-related health problems (motion sickness, venous thrombosis, motor vehicle injuries, bloodborne and sexually transmitted diseases (STDs), water and airborne injuries, dermatologic conditions, respiratory tract infections and tuberculosis, rabies and animal-related diseases, etc.) and preventive measures.

\section{Motion sickness/car sickness:}

- Avoid eating rich and spicy food before traveling,

- Do not read books or play with a computer or telephone while the vehicle is in motion,

- Sit in a central position in the vehicle and face the same direction as the vehicle's direction of movement,

- Carry meclizine tablets or scopolamine patches/bands ${ }^{[22]}$.

Venous thrombosis:

Pregnant women, women using oral contraceptives, individuals planning to travel for more than 5 hours, smokers, and those 
with coagulopathy, malignancy, coronary artery disease, and history of venous thrombosis are at risk.

- Stand and walk around every 1-2 hours during the journey,

- Wear comfortable clothing, avoid close-fitting clothes,

- Frequently change position while sitting in the vehicle,

- Frequently flex and stretch legs,

- Wear compression stockings ${ }^{[23]}$.

Injuries and traffic accidents:

- Do not drive when drunk or sleepy,

- Fasten seatbelt,

- Do not drive a motorcycle, and use helmet even when you are the passenger,

- Do not drive at night or drive to destinations far from city centers $^{[7]}$.

\section{Bloodborne and STDs:}

Diseases such as human immunodeficiency virus (HIV), hepatitis $B$ virus, hepatitis $C$ virus (HCV), herpes simplex virus 1 and 2 , gonorrhea, chlamydia, and syphilis are bloodborne or sexually transmitted. Vaccines (other than hepatitis A and B) and medicines do not provide protection against STDs. Instruction on safe sex practice and the importance of using condoms is essential for protection against STDs.

A meta-analysis determined that being male, traveling alone for long periods, traveling for sex tourism, greater number of sexual partners, homosexuality and bisexuality, not using condoms, intercourse with sex workers, and using alcohol and intravenous (IV) drugs increased risk of contracting bloodborne diseases and STDs ${ }^{[24]}$.

Barrier methods other than condoms do not prevent HIV infection. The use of spermicides alone is not protective against infection. Individuals with latex allergy should use condoms made of polyurethane or other synthetic materials ${ }^{[25]}$.

- Whether male or female, use condoms throughout any type of sexual intercourse,

- Avoid intercourse with sex workers,

- Avoid using alcohol or addictive drugs during travel (especially due to decreased social pressure),

- Refrain from activities that compromise dermal integrity such as acupuncture, piercing, and tattoo,

- Avoid surgical procedures unless there is a life-threatening situation (such as dental procedures),

- Avoid sharing needles with drug addicts ${ }^{[7]}$.
Waterborne and marine diseases:

- Avoid swimming where there is sewage contamination or algae,

- Avoid swimming or participating in water sports at night or when drunk,

- Avoid aquatic activities in areas where schistosomiasis is endemic (Africa, South America, the Caribbean, the Middle East, South China, Southeast Asia, and the Philippines),

- Use proper footwear when walking or swimming in order to avoid parasites and injury from poisonous plants and animals,

- Be vigilant for jellyfish, sea urchins, and corals when in tropical waters $^{[7]}$.

\section{Dermatologic diseases:}

- Broken skin is vulnerable to infections. Therefore, in case of any cut or injury, the affected area should be thoroughly cleaned with soapy water and antiseptic solution ${ }^{[7]}$,

- It should be kept in mind that dermatological diseases may develop and progress more rapidly in hot climates due to increased perspiration, and may require antimicrobial treatment ${ }^{[26]}$.

\section{Respiratory tract infections and tuberculosis:}

- Avoid using public transportation if possible, since crowded public transportation vehicles are usually poorly ventilated,

- Stay away from people with severe and/or persistent cough,

- Avoid outdoor activities at times of intense air pollution,

- If you are planning a long trip, taka a tuberculosis skin test before departing and after returning home ${ }^{[7]}$.

Rabies and animal-related diseases:

- Do not touch or feed wild animals or unknown pets,

- If you are attacked/hurt by an animal, go to a healthcare center for tetanus and rabies vaccinations ${ }^{[7]}$.

c) Prepare a personal medical equipment kit (adhesive bandages, antiseptics, gauze, thermometer, antipyretics and analgesics, gastroprotective/antiacid medicines, sunblock, insect-repellent, and condoms); prepare a card describing the traveler's medical history and carry during the travel ${ }^{[7]}$.

\section{Reviewing the Routine Vaccination Schedule}

Some vaccine-preventable diseases are becoming rare in developed and developing countries thanks to routine childhood immunization. However, these diseases may be more prevalent in countries with inadequate childhood immunization and may be carried by travelers back to countries in which they are rare ${ }^{[27]}$. 
The current routine childhood immunization schedule in Turkey includes hepatitis B and A, Bacille Calmette-Guerin, diphtheria, acellular pertussis, tetanus, Td (tetanus, diphtheria toxoid), inactivated poliovirus vaccine (IPV), oral poliovirus vaccine (OPV), Haemophilus influenzae type b (Hib), pneumococcal conjugate, measles, mumps, rubella (MMR), and chicken pox vaccines $^{[28]}$.

In Turkey, adults born after 1980 who lack documentation of receiving measles or rubella vaccine or record of having those diseases should receive at least 1 dose of subcutaneous MMR vaccine. Healthcare personnel or individuals planning to travel internationally should receive a second dose of MMR vaccine at least 28 days later ${ }^{[29]}$. The protection ratios of the childhood MMR vaccine against MMR are $94 \%, 97 \%$, and $94 \%$, respectively, and the resulting antibodies provide lifelong protection. MMR vaccination after contact with infected individuals does not protect against mumps and rubella ${ }^{[30]}$. The vaccine is contraindicated for immunosuppressed patients, pregnant women, women planning on becoming pregnant in the next four weeks, and people with anaphylactic allergic reactions to gelatin and neomycin. These individuals should not be vaccinated after exposure to measles, but be given $0.5 \mathrm{~mL} / \mathrm{kg}$ standard immunoglobulin intramuscularly (IM) within six days ${ }^{[29]}$.

Td booster doses are recommended every ten years. Travel does not increase risk for the disease. A booster shot is recommended every 5 years if traveling to a country with limited access to healthcare services and poor hygienic conditions or the trip will involve activities with high risk of injury, such as trekking and safari. Even with complete childhood immunization, the antibodies against pertussis decline over time, so it is imperative that one of the boosters given to adults is $\mathrm{Td}$ acellular pertussis $\left(\right.$ Tdap $^{\left[{ }^{[31]}\right.}$. The protection ratio of the $\mathrm{Td}$ vaccine is around $95 \%{ }^{[32]}$. The vaccination is contraindicated if previously followed by severe allergic reactions or neurological symptoms ${ }^{[29]}$.

Hepatitis A virus (HAV) is transmitted by consuming contaminated water and food and through direct contact with infected people ${ }^{[33]}$. The infection is symptomatic in $30 \%$ of patients aged 6 or younger, whereas $70 \%$ of infected adults develop symptoms such as hepatitis, nausea, and fatigue. Travelers should drink clean water, eat well-cooked food, and refrain from consuming food sold by street vendors to avoid HAV infection ${ }^{[34]}$. Hepatitis A vaccine is recommended for seronegative tourists traveling to moderately to highly endemic regions. There are three types of vaccines: live attenuated (licensed in China), inactivated, and combined hepatitis A and B vaccines ${ }^{[29]}$. For lifetime protection, inactived hepatitis A vaccine should be given in 2 doses at an interval of 6-12 months. The level of protective antibodies is generally $94-100 \%$ at 1 month after a single dose of vaccine ${ }^{[33]}$. There are no contraindications for the inactivated vaccine other than severe hypersensitivity reaction after a previous dose ${ }^{[29]}$.
Hepatitis B infection is one of the leading vaccine-preventable diseases. Routes of transmission include mucosal contact with infected blood and body fluids, needle sharing among IV drug users, sex with an infected partner, and vertical transmission from mother to baby during birth ${ }^{[35]}$. Vaccination is recommended for all nonimmune visitors (born after 1998) to countries with medium to high endemicity (2-10\% HBsAg prevalence). The hepatitis $B$ vaccine contains major surface antigen produced using recombinant DNA technology and is administered as three doses given at day 0 and at 1 and 6 months. The accelerated schedule (days 0,7 , and 21 and at 12 months) may be applied if necessary. The level of protective antibodies after the third dose is approximately $90 \%$. The vaccine is contraindicated in persons with history of hypersensitivity to any of its components ${ }^{[2]}$.

The chickenpox virus is highly infectious. It is transmitted via aerosols and direct contact. Vaccination is recommended for all seronegative persons planning international travel. The vaccine is administered as two doses given at an interval of 4-8 weeks. The protection rate of the vaccine 6 weeks after the second dose is $95 \%$. It is contraindicated for individuals with congenital and acquired immune deficiency, malignancy, and women who are pregnant or planning to become pregnant within four weeks of receiving the vaccine ${ }^{[36]}$.

Influenza risk during travel varies depending on the season. The risk increases during winter and rainy seasons. Therefore, influenza immunization should be performed before winter ${ }^{[29]}$. Trivalent and quadrivalent inactivated influenza vaccines are recommended for the 2017-2018 season. The protection rate is around $60 \% \%^{[37]}$.

In countries where Hib vaccination is routine, Hib infections have almost been eradicated. Vaccination is suggested for specific adult groups with increased risk of disease. These groups include persons with splenectomy, acquired immune deficiency, hematopoietic stem cell transplant, and immunoglobulin or complement deficiency ${ }^{[29]}$. Four doses of conjugated vaccine have a protection rate of 99\%. The vaccine is contraindicated for persons with history of severe allergic reaction to a previous dose ${ }^{[38]}$.

Streptococcus pneumoniae is an invasive pathogen that can cause serious infections such as meningitis, pneumonia, and bacteremia. There are two types of pneumococcal vaccines: the conjugate vaccine, recommended as a single dose, and polysaccharide vaccine, which is repeated up to three times at intervals of 5 years ${ }^{[29]}$. Pneumococcal conjugate vaccine is recommended for all individuals under 2 and over 65 years of age. Children and adults between the ages of 2 and 65 years should also be vaccinated if they have cerebrospinal fluid (CSF) leak, cochlear implant, hemoglobinopathies such as sickle cell anemia, functional or anatomic asplenia, congenital or acquired immunodeficiency, chronic kidney disease and 
nephrotic syndrome, leukemia, lymphoma, multiple myeloma, solid organ transplant, or disseminated cancer. Pneumococcal polysaccharide vaccine is recommended as a single dose for children and adults 2-65 years of age with congestive heart failure, chronic obstructive lung disease, diabetes, CSF leak, cochlear implant, alcoholism, and chronic liver disease. Two doses of pneumococcal polysaccharide vaccine at an interval of five years is recommended for those with congenital or acquired immunodeficiency, chronic kidney disease or nephrotic syndrome, leukemia, lymphoma, Hodgkin's disease, disseminated cancer, solid organ transplant, and multiple myeloma. The polysaccharide vaccine is repeated at five years because it stimulates humoral immunity and does not provide permanent protection ${ }^{[39]}$. The protection rate of pneumococcal polysaccharide vaccine against invasive pulmonary diseases is $60-70 \%$. The protection rate of the pneumococcal conjugate vaccine against the serotypes it contains is $75 \% 0^{[40]}$. Persons at risk and those over the age of 65 years should receive a pneumococcal polysaccharide or conjugate vaccine at least 10 days before traveling. It is contraindicated for people who are hypersensitive to the vaccine or its contents ${ }^{[29]}$.

Poliovirus affects the nervous system. It is transmitted from person to person and through contaminated food, and causes acute flaccid paralysis ${ }^{[4]]}$. There are two types of vaccine, the live attenuated OPV and the IPV. Both are included in the childhood immunization program in Turkey ${ }^{[42]}$. After three doses of IPV vaccine, the protective efficacy is $99-100 \% \%^{[43]}$. Even for individuals with complete childhood immunizations, a single dose of IPV is required if before traveling to polio endemic areas (Afghanistan, Pakistan, Nigeria) if more than ten years have passed since the last dose $\mathrm{e}^{[4]]}$. OPV is contraindicated for individuals with congenital or acquired immunodeficiency, widespread malignancy, lymphoma, leukemia, or household contacts of immunocompromised persons ${ }^{[29]}$.

The pretravel health consultation should include serologic testing for $\mathrm{HBsAg}$, anti-HBs, anti-HAV IgG, measles IgG, rubella IgG, mumps IgG, and varicella IgG. Seronegative individuals with no contraindications should be vaccinated. Travelers should be evaluated in the THC for routine immunization status and they are referred to their primary care physician to complete any missing vaccinations.

\section{Region-Specific Travel Vaccinations}

These are vaccinations considered beneficial for travelers according to the disease risk in the travel destination ${ }^{[7]}$. Typhoid is an acute, life-threatening disease transmitted through contaminated water and food. The symptoms are malaise, fatigue, headache, abdominal pain, constipation, and fever. Consuming clean/safe water and food and practicing good personal hygiene are the primary methods of preventing typhoid. There are two types of typhoid vaccines, a Vi capsular polysaccharide vaccine (parenteral, IM) and a live attenuated (oral) vaccine. The live vaccine is given to persons over the age of 6 years as four doses at intervals of 48 hours, followed by a booster shot every 5 years. The polysaccharide vaccine is given to persons aged >2-years as a single IM dose which protects for approximately two years. Risk is higher in regions such as Asia, Africa, and Latin America. Travelers to those destinations should be vaccinated at least one week before departure. Currently available vaccines have a protective efficacy of 50-80\% against Salmonella typhi. Therefore, even vaccinated individuals must continue to take precautions to avoid infection ${ }^{[44]}$. The polysaccharide typhoid vaccine is available at THCs in Turkey ${ }^{[45]}$.

Japanese encephalitis is a potentially fatal viral disease transmitted by mosquitoes of the genus Culex. It is endemic in Asia and the western Pacific. The risk of infection varies depending on the travel destination, duration of stay in rural areas, activities, and season. There is high risk of infection in Asia during summer and autumn. In tropical and subtropical regions, infection is possible throughout the year. However, the risk is higher during the monsoon (rainy) season. Visiting rural areas, riding bicycles, sports such as mountaineering, and activities that involve being outside after dark increase the risk of infection. Fewer than 1\% of patients are symptomatic. In severe cases, infection leads to encephalitis with fever, headache, vomiting, and mental status changes. The mortality rate in symptomatic patients is in the range of $20-30 \%$. There is no specific antiviral treatment for Japanese encephalitis. Therefore, preventive measures are the main priority. Travelers should take precautions to prevent mosquito bites and should be vaccinated against the viral agent ${ }^{[46]}$. There are two types of vaccines, the inactivated Vero cell culture derived vaccine is approved for use in the USA while the live attenuated vaccine is used in Asia (SA 14-14-2 strain) ${ }^{[29]}$. Individuals who plan to spend over 1 month in endemic rural areas or to participate in outdoor activities in rural areas should be vaccinated ${ }^{[45]}$. The vaccine is administered in two doses by IM injection at an interval of 28 days. The second dose should be given at least one week before departure to provide adequate protection. It has been shown that neutralizing antibodies were produced in 96\% of adults following the two doses of vaccine, and protection persisted for three years ${ }^{[46]}$. The vaccine is not recommended for people with hypersensitive reaction to a previous dose or for pregnant women ${ }^{[45]}$.

Tickborne encephalitis is transmitted by the bite of Ixodes spp. ticks and causes signs of meningeal irritation. It is locally endemic in parts of Europe and Asia. Although most cases are reported in Russia, it is also common in Serbia, Slovenia, Estonia, Albania, Finland, Sweden, Denmark, France, China, 
Japan, and North Korea. Vaccination is recommended for persons planning a long stay in highly endemic regions and for those who will camp in forested areas ${ }^{[29]}$. There are two inactivated cell culture-derived vaccines approved in Europe and another two in Russia. The European vaccines are given in three doses, while the Russian vaccines are given in two IM doses. The vaccines have an efficacy of over 95\% and a booster shot is recommended every three years ${ }^{[47]}$. Pregnant women may be vaccinated if necessary ${ }^{[45]}$.

Toxigenic Vibrio cholerae is the cause of acute bacterial diarrhea. Transmission occurs through contaminated water and food. It may lead to extreme dehydration due to nausea, vomiting, and watery diarrhea. With proper fluid replacement, mortality is less than 1\%. It is endemic in about 50 countries, particularly those in Africa and South Asia. There is one oral live attenuated vaccine certified by the U.S. Food and Drug Administration. It is given as a single dose to individuals aged between 18 and 64-years. Ten days after vaccination, the protective efficacy is $90 \%$. There are no studies on its use during pregnancy and breastfeeding ${ }^{[48]}$. There are two killed whole-cell vaccines certified by the World Health Organization. They are given orally as two doses with one week interval. The protective efficacy of these vaccines is reported to be $66-86 \%$. A booster dose is recommended after two years ${ }^{[49]}$. The single-dose live attenuated oral vaccine is suggested for travelers to endemic regions and for relief workers, refugees, and healthcare personnel in epidemic areas ${ }^{[50]}$.

Rabies is an acute and fatal viral encephalomyelitis. Many wild and domestic animals are reservoirs for the disease. Transmission to humans occurs through viral inoculation by the bite of an infected animal. Two prophylactic rabies vaccination schedules are implemented. Pre-exposure rabies vaccination is administered $\mathrm{IM}$ in three doses on days 0,7 , and 21 to persons who plan to areas or participate in activities that increase the risk of rabies. High-risk groups include individuals staying for long periods in Latin America, Southeast Asia, or Africa; cyclists; hikers and mountaineers; cavers; young children; and frequent travelers. Post-exposure rabies prophylaxis is given in four doses on day $0,3,7$, and 14 after contact. Pregnancy is not a contraindication for rabies vaccine ${ }^{[51]}$. Vaccines for Japanese encephalitis, tickborne encephalitis, and cholera are not available in Turkey. Travel Health Centers inform travelers who are at risk for these diseases and recommend being vaccinated in the destination country.

\section{Obligatory Vaccinations}

Neisseria meningitidis causes purulent bacterial meningitis. Based on their capsular polysaccharides, strains are classified into six serotypes, $A, B, C, W, X$ and $Y$. It is spread from person to person by close contact and droplet transmission. It is common in sub-Saharan African countries. Epidemics usually occur between December and June. There are polysaccharide and polysaccharide conjugate vaccines containing serogroup $A, C$, $Y$, and W135 and there is another vaccine against serogroup B. Although meningococal conjugate vaccine is not included in childhood immunization schedule in Turkey, it is given in Europe at the age of 12 and 16 years old ${ }^{[52]}$. Meningococcal vaccines conjugated to diphtheria or tetanus toxoids are available in Turkey. Conjugate vaccines are given between the ages of 2 and 55 years. There is also a tetravalent polysaccharide vaccine that may be given to individuals aged 55 or over. Meningococcal vaccination is required by Saudi Arabia for visitors to Mecca and Medina for hajj and umrah. Community health centers in Turkey routinely give the tetravalent ACWY polysaccharide vaccine to persons intending to travel for Hajj pilgrimage ${ }^{[53]}$. The vaccine has approximately $85 \%$ protective efficacy for three years, and a booster dose is recommended after five years for adults at risk ${ }^{[29]}$. Hypersensitivity to the vaccine or any of its components is a contraindication for the vaccine. Because all meningococcal vaccines are inactivated, they may be given to immunosuppressed patients. They are not contraindicated for pregnant and breastfeeding women ${ }^{[52]}$.

Yellow fever is a viral disease transmitted via the bite of infected Aedes or Haemagogus mosquitoes. Clinical presentation ranges from asymptomatic to septic shock. The case-fatality ratio among patients with hepatorenal damage is 20-50\%. There is no specific treatment for yellow fever. Protection against mosquitoes should be practiced for prevention. All persons over the age of 9 months traveling to South America and Africa should be administered a single-dose subcutaneous vaccine. The vaccine is contraindicated for infants aged $<6$ months old and individuals with a history of hypersensitivity to the vaccine or its components, HIV infection with CD4 T Iymphocyte count under 200/ $\mathrm{mm}^{3}$, malignancies, transplantation, and congenital or acquired immunodeficiency. There have been no large studies regarding the safety of this live attenuated vaccine during pregnancy and breastfeeding, and thus caution should be exercised ${ }^{[54]}$. The vaccine has over 90\% protective efficacy. Protective antibody titers decrease within ten years, but a booster dose is not recommended ${ }^{[55]}$. An International Certificate of Vaccination or Prophylaxis (ICVP) must be presented as proof of yellow fever vaccination when entering countries such as the Republic of the Congo, Angola, Ghana, Liberia, and Nigeria ${ }^{[45,54]}$. The vaccine is only available at THCs. Only THCs of the Directorate General of Health Services for Borders and Coasts of Turkey are authorized to issue the ICVP ${ }^{[15]}$. Recommended pretravel immunizations are summarized in Tables 1, 2, and 3. 
Table 1. Pretravel immunization recommendations routine vaccinations

\begin{tabular}{|c|c|c|c|}
\hline Disease and vaccine type & $\begin{array}{l}\text { Route of administration, } \\
\text { vaccination schedule protection } \\
\text { rate }(\%)\end{array}$ & Travel destination & Special patient population[21] \\
\hline MMR (live attenuated) & SC, 2 doses 28 days apart & No specific region & $\begin{array}{l}\text { International travelers and } \\
\text { healthcare workers }\end{array}$ \\
\hline $\mathrm{Td}$ & IM, booster after 10 years, 95\%[24] & No specific region & $\begin{array}{l}\text { Booster after } 5 \text { years if traveling } \\
\text { to countries with limited access to } \\
\text { healthcare services or poor hygienic } \\
\text { conditions }\end{array}$ \\
\hline $\begin{array}{l}\text { Hepatitis A (inactivated } \\
\text { virus) }\end{array}$ & $\begin{array}{l}\text { IM, } 2 \text { doses 6-12 months apart, } \\
94-100 \% 0^{[25]}\end{array}$ & $\begin{array}{l}\text { Countries other than low endemic } \\
\text { countries such as Australia, } \\
\text { Canada, Western Europe, Japan, } \\
\text { and New Zealand }{ }^{[26]}\end{array}$ & $\begin{array}{l}\text { IV drug addicts, daycare and } \\
\text { preschool personnel, patients with } \\
\text { chronic liver disease, sewer workers, } \\
\text { and cleaners }\end{array}$ \\
\hline $\begin{array}{l}\text { Hepatitis B (recombinant } \\
\text { DNA vaccine) }\end{array}$ & $\begin{array}{l}\text { IM, } 3 \text { doses at ages } 0,1, \text { and } 6 \\
\text { months } \\
\text { Accelerated schedule: } 0,7,21 \text { days } \\
\text { and } 12 \text { months, } 90 \% 0^{[21]}\end{array}$ & $\begin{array}{l}\text { Countries with medium to high } \\
\text { endemicity (the Middle East, } \\
\text { North Africa, Southeast Asia, } \\
\text { South America, and Central-South } \\
\text { Africa) }{ }^{[21]}\end{array}$ & $\begin{array}{l}\text { Healthcare workers, hemodialysis } \\
\text { patients, IV drug addicts, sex } \\
\text { workers, homosexuals, and those } \\
\text { who frequently use blood products, } \\
\text { such as hemophiliacs }\end{array}$ \\
\hline Polio (live and inactivated) & $\begin{array}{l}\text { - Oral live vaccine, } 1 \text { dose } \\
\text { - IM, inactivated vaccine, } 1 \text { dose, } \\
99-100 \% 0^{[33]}\end{array}$ & $\begin{array}{l}\text { Afghanistan, Myanmar, Guinea, } \\
\text { Laos, Madagascar, Nigeria, } \\
\text { Pakistan }^{[35]}\end{array}$ & No special patient group \\
\hline
\end{tabular}

MMR: Measles, mumps, rubella, Td: Tetanus and diphtheria toxoid, SC: Subcutaneous, IM: Intramuscular, IV: Intravenous

Table 2. Pretravel immunization recommendations recommended vaccinations by region

\begin{tabular}{|c|c|c|c|}
\hline Disease and vaccine type & $\begin{array}{l}\text { Route of administration, vaccination } \\
\text { schedule, protection rate }(\%)\end{array}$ & Travel destination & $\begin{array}{l}\text { Special patient } \\
\text { population }\end{array}$ \\
\hline Typhoid vaccine & $\begin{array}{l}\text { - Live attenuated bacteria vaccine / oral / } \\
4 \text { doses with intervals of } 2 \text { days / must be } \\
\text { completed } 1 \text { week before travel, booster } \\
\text { after } 5 \text { years } \\
\text { - Inactivated vaccine / IM / } 1 \text { dose / must } \\
\text { be completed } 2 \text { weeks before travel, booster } \\
\text { after } 2 \text { years, } 50-80 \%[36]\end{array}$ & $\begin{array}{l}\text { India, Egypt, Morocco, West } \\
\text { Africa, Peru }{ }^{[36]}\end{array}$ & $\begin{array}{l}\text { Laboratory workers and } \\
\text { persons in close contact } \\
\text { with typhoid carriers }\end{array}$ \\
\hline $\begin{array}{l}\text { Japanese encephalitis vaccine } \\
\text { (live attenuated) }\end{array}$ & $\begin{array}{l}\text { IM, } 2 \text { doses } 28 \text { days apart, } \text {, the last dose } \\
\text { should be at least } 1 \text { week before trip, 96\%[0 }\end{array}$ & $\begin{array}{l}\text { Japan, China, Korea, } \\
\text { Cambodia, Myanmar, } \\
\text { Bangladesh, India, Indonesia, } \\
\text { Singapore, the Philippines }{ }^{[38]}\end{array}$ & $\begin{array}{l}\text { Travelers visiting rural } \\
\text { areas, those who may } \\
\text { stay more than } 30 \text { days in } \\
\text { an endemic area }\end{array}$ \\
\hline $\begin{array}{l}\text { Tickborne encephalitis vaccine } \\
\text { (inactivated) }\end{array}$ & IM, 3 doses at 0,1 , and 12 months, 95\% $0^{[39]}$ & $\begin{array}{l}\text { Russia, Czech Republic, } \\
\text { Estonia, Germany, Hungary, } \\
\text { Latvia, Lithuania, Poland, } \\
\text { Slovenia, Switzerland, China, } \\
\text { Japan, Mongolia, and South } \\
\text { Korea }^{[21]}\end{array}$ & $\begin{array}{l}\text { Individuals camping in } \\
\text { wooded areas or in fields, } \\
\text { agricultural workers, and } \\
\text { persons planning to stay } \\
\text { long-term in endemic } \\
\text { regions }\end{array}$ \\
\hline Cholera vaccine (live attenuated) & Oral, 2 doses 1 week apart, 66-86\%[0 & $\begin{array}{l}\text { Dominican Republic, India, } \\
\text { Tanzania, Cuba, and Haiti }{ }^{[21]}\end{array}$ & $\begin{array}{l}\text { Individuals staying } \\
\text { long-term in immigrant } \\
\text { camps, patients who } \\
\text { have achlorhydria, use } \\
\text { antacids, or have had } \\
\text { gastric resection }\end{array}$ \\
\hline
\end{tabular}


Table 3. Pretravel immunization recommendations compulsory vaccinations

\begin{tabular}{l|l|l|l}
\hline Disease and vaccine type & $\begin{array}{l}\text { Route of administration, vaccination } \\
\text { schedule, protection rate (\%) }\end{array}$ & Travel destination & Special patient population $^{[21]}$ \\
\hline $\begin{array}{l}\text { Yellow fever vaccination } \\
\text { (live attenuated) }\end{array}$ & $\begin{array}{l}\text { SC, } 1 \text { dose, } 96 \% 0^{[46]} \\
\text { (booster not recommended) }\end{array}$ & $\begin{array}{l}\text { Burundi, Central African Republic, } \\
\text { Republic of Congo, Angola, } \\
\text { Liberia, Nigeria, Ghana, Sierra } \\
\text { Leone, and Gabon }{ }^{[37]}\end{array}$ & No special patient group \\
\hline $\begin{array}{l}\text { Meningococcal vaccination } \\
\text { (polysaccharide vaccine) }\end{array}$ & $\mathrm{IM}, 1$ dose booster after 5 years, 85\% $0^{[21]}$ & $\begin{array}{l}\text { Sub-Saharan countries, Tanzania, } \\
\text { Somalia, and Ethiopia }\end{array}$ & $\begin{array}{l}\text { Required for potential pilgrims } \\
\text { traveling to Saudi Arabia }\end{array}$ \\
\hline
\end{tabular}

SC: Subcutaneous, IM: Intramuscular

\section{Malaria Prophylaxis for Travelers to Areas of Risk}

Every year almost 50 million people travel from industrialized countries to tropical regions where malaria is endemic. Malaria is one of the most important causes of fever during international travel. It is the most important life-threatening tropical disease that requires immediate treatment ${ }^{[3]}$.

Malaria prevention measures can be grouped under four headings ${ }^{[3]}$ :

1. Be aware of the level of risk in the destination and of malaria symptoms,

2. Take measures to avoid mosquito bites, and travel during the day,

3. Use appropriate chemoprophylaxis (based on distribution of malaria along the planned route, the common malaria agent, drug resistance profiles of varieties common in the region, the probability of deviation from the travel route, duration of travel, and individual drug tolerance),

4. Consider malaria if any febrile illness develops up to three months after travel.

In daily practice, atovaquone-proguanil is the most preferred chemoprophylaxis for short-term travel. Treatment can be discontinued seven days after returning from travel. It has the advantage of fewer side effects but has higher cost ${ }^{[56]}$.

Weekly mefloquine is preferred for long-term travel due to its low cost and convenience. It is not recommended for pregnant women. The main side effect of mefloquine is neuropsychiatric symptoms. Therefore, when possible, individuals should start taking mefloquine three weeks before travel in order to assess their tolerability ${ }^{[56]}$. Doxycycline is an expensive prophylaxis used daily. It may cause severe gastric side effects. It is not recommended for children under the age of 8 years or for pregnant women ${ }^{[57]}$.

Chloroquine, an old medicine taken weekly, is quite effective in certain regions where chloroquine-sensitive parasites are found. Chloroquine resistance is nearly universal in Plasmodium falciparum. Chloroquine is still effective only in Mexico, Central America west of Panama Canal, the Caribbean, East Asia, and some Middle Eastern countries. It may also be given to all age groups and to pregnant women ${ }^{[57]}$.

Hypnozoites that remain dormant in the liver following Plasmodium vivax or Plasmodium ovale infection may cause relapses many months or, in rare cases, several years later. The primary prophylactic medicines (atovaquone-proguanil, doxycycline, and mefloquine) are ineffective against hypnozoites in the liver. Therefore, primaquine should be considered for prophylaxis when traveling to areas where $P$. vivax is endemic. This strategy also helps reduce the risk of relapse. Primaquine may be administered to children but is not recommended for pregnant women. In the prophylaxis schedule, the medication is started one day before travel and used daily until seven days after returning ${ }^{[58]}$.

All prophylactic agents except doxycycline are available at THCs. Travelers are given up to one month of the appropriate prophylactic agent based on their personal circumstances and duration of stay. For doxycycline, the prescription may be given by the primary care physician or an infectious diseases specialist ${ }^{[15]}$. The agents used for malaria prophylaxis are summarized in Table 4.

Education About Avoiding and Treating Traveler's Diarrhea

Diarrhea is the most common illness faced by travelers to developing countries. Traveler's diarrhea is defined as diarrhea that develops after the first day of travel and within the first seven days after returning. The symptoms include passing unformed stools three or more times a day, fever, stomachache, nausea, and vomiting. Bacteria are the most common cause, and the agent is usually enterotoxigenic Escherichia coli (ETEC). The risk is reduced by practicing personal hygiene rules ${ }^{[59]}$.

Protective measures that travelers should take include practicing meticulous hand hygiene; avoiding food sold by street vendors or is left out or unprotected from flies; avoiding undercooked meat and poultry, cold sausages, and salads; and using clean water for drinking and tooth-brushing ${ }^{[59]}$.

Travelers should be informed on self-treatment of diarrhea. A single dose of quinolone (ciprofloxacin $500 \mathrm{mg}$ ) is generally 
Table 4. Features of agents used for malaria prophylaxis ${ }^{[47]}$

\begin{tabular}{|c|c|c|}
\hline Prophylactic agent & $\begin{array}{l}\text { Initiation, discontinuation, and } \\
\text { frequency }\end{array}$ & Advantages and disadvantages \\
\hline $\begin{array}{l}\text { Chloroquine ( } 500 \mathrm{mg} \\
\text { salt/300 mg base) (only } \\
\text { in areas with chloroquine } \\
\text { sensitivity) }\end{array}$ & $\begin{array}{l}\text { Started } 1 \text { week before travel } \\
\text { Taken once a week } \\
\text { Continued for } 4 \text { weeks } \\
\text { after return. }\end{array}$ & $\begin{array}{l}\text { Taking once a week is convenient } \\
\text { Can be used by pregnant women and children } \\
\text { Prolonged use can cause retinopathy } \\
\text { Starting one week before departure makes it unsuitable for spontaneous } \\
\text { travel }\end{array}$ \\
\hline $\begin{array}{l}\text { Atovaquone-proguanil } \\
(250 \mathrm{mg} / 100 \mathrm{mg})\end{array}$ & $\begin{array}{l}\text { Started } 1 \text { week before travel } \\
\text { Taken once a day } \\
\text { Continued for } 1 \text { week after return. }\end{array}$ & $\begin{array}{l}\text { Cannot be used by women who are pregnant or nursing infants under } 5 \\
\mathrm{~kg} \\
\text { Taking daily may result in noncompliance } \\
\text { There are few side effects } \\
\text { Not appropriate for patients with kidney failure } \\
\text { More expensive than other prophylactic agents }\end{array}$ \\
\hline Mefloquine (250 mg) & $\begin{array}{l}\text { Started } 2 \text { weeks before travel } \\
\text { Taken once a week } \\
\text { Continued for } 4 \text { weeks } \\
\text { after return. }\end{array}$ & $\begin{array}{l}\text { Can be used in the second and third trimesters of pregnancy } \\
\text { Cannot be used in regions with mefloquine resistance } \\
\text { Taking once a week is convenient, making it preferable for long trips } \\
\text { Not recommended for those with history of seizures or those with } \\
\text { psychiatric and cardiac problems } \\
\text { Starting } 2 \text { weeks before departure makes it unsuitable for spontaneous } \\
\text { travel }\end{array}$ \\
\hline Doxycycline (100 mg) & $\begin{array}{l}\text { Started } 1 \text { week before travel } \\
\text { Taken once a day } \\
\text { Continued for } 4 \text { weeks } \\
\text { after return. }\end{array}$ & $\begin{array}{l}\text { Cannot be used by pregnant women and children under } 8 \text { years old } \\
\text { The least expensive agent } \\
\text { Severe gastric side effects } \\
\text { Taking daily may result in noncompliance }\end{array}$ \\
\hline Primaquine (15 mg base) & $\begin{array}{l}\text { Started } 1 \text { day before travel } \\
\text { Taken once a day } \\
\text { Continued for } 1 \text { week } \\
\text { after return. }\end{array}$ & $\begin{array}{l}\text { Cannot be used by women who are pregnant or nursing infants under } 5 \\
\text { kg } \\
\text { Taking daily may result in noncompliance } \\
\text { Cannot be used by those with glucose-6-phosphate dehydrogenase } \\
\text { (G6PD) deficiency }\end{array}$ \\
\hline
\end{tabular}

effective. Ciprofloxacin twice daily for 3 days can be recommended if symptoms persist. Because quinolone-resistant Campylobacter jejuni is common in Southeast Asia or India, azithromycin is recommended as a single dose of 1 gram or as $500 \mathrm{mg} /$ day for 3 days to travelers in those areas ${ }^{[59]}$.

\section{Approach to Posttravel Infections}

Firstly, a detailed medical history should be taken. Information should be gathered regarding any symptoms and findings present, the destination and route of travel, the season of travel, activities during travel, exposure to environmental factors, pretravel immunization, and compliance with protective measures. This should be followed by systemic physical examination. The physician should make two lists of prediagnoses in light of these findings. One list should include the usual diseases that produce the patient's symptoms and the other list consists of possible travel-related diseases. It should be kept in mind that some diseases have long incubation periods (malaria, schistosomiasis, filariasis, rickettsial diseases, brucellosis, babesiosis, leishmaniasis, hepatitis, etc.) and therefore TRIs may develop even months after travel ${ }^{[3]}$.
Numerous studies have determined the most frequent posttravel symptoms are febrile illnesses, gastrointestinal complaints, dermatologic diseases, and respiratory tract infections ${ }^{[3,4]}$. Febrile illnesses are more common in travels to sub-Saharan Africa, traveler's diarrhea in Southern-Central Asia, and dermatologic diseases in sub-Saharan Africa and Southern-Central Asia ${ }^{[3]}$.

A multicenter study conducted in Turkey by Erdem et al. ${ }^{[60]}$ investigated infections diagnosed in pilgrims who traveled to Arabia. Respiratory tract infections (91\%) and gastroenteritis (7\%) were the most common diagnoses. Only 30 of the 185 patients who returned from pilgrimage were found to have infectious agents. Twenty-one were viral and 9 were bacterial agents. Mortality was reported to be $1.1 \%$. In this section, the infections that most commonly cause these clinical syndromes in patients returning from travel are discussed in light of epidemiological data.

\section{Febrile IIInesses}

Fever occurs in 20\% of patients who become ill after travel. Although the most common cause of fever varies by travel 
Table 5. Travel-related febrile illnesses

\begin{tabular}{|c|c|c|c|}
\hline Disease & Incubation & Regions & Signs and symptoms \\
\hline Malaria & 6 days-years ${ }^{[51]}$ & Tropical / subtropical regions ${ }^{[53]}$ & $\begin{array}{l}\text { Fever, influenza-like illness, head and muscle pain, } \\
\text { mental status changes, kidney failure, respiratory } \\
\text { failure. Thrombocytopenia, elevated liver enzymes }\end{array}$ \\
\hline Dengue & 4-7 days ${ }^{[56]}$ & $\begin{array}{l}\text { America, Southeast Asia, Eastern } \\
\text { Mediterranean, Western Pacific, and } \\
\text { Africa }^{[56]}\end{array}$ & $\begin{array}{l}\text { Fever, severe headache, retroorbital pain, joint and } \\
\text { muscle pain. Thrombocytopenia, elevated liver } \\
\text { enzymes }^{[56]}\end{array}$ \\
\hline Chikungunya & $1-12$ days $^{[52]}$ & $\begin{array}{l}\text { India, Malaysia, Singapore, the } \\
\text { Caribbean }{ }^{[52]}\end{array}$ & $\begin{array}{l}\text { Fever, head and muscle pain, widespread macular } \\
\text { rash, tenosynovitis }\end{array}$ \\
\hline Zika & $\begin{array}{l}\text { Not known, } 2 \text { weeks } \\
\text { average }^{[68]}\end{array}$ & Asia and Africa ${ }^{[68]}$ & $\begin{array}{l}\text { Fever, maculopapular rash, conjunctivitis, } \\
\text { arthralgia }^{[68]}\end{array}$ \\
\hline Enteric fever & 6-30 days ${ }^{[57]}$ & India ${ }^{[57]}$ & $\begin{array}{l}\text { Influenza-like illness, frontal headache, nausea, and } \\
\text { vomiting. Hepatosplenomegaly, rose spots on chest } \\
\text { and abdomen, and relative bradycardia may be } \\
\text { present }{ }^{[57]} \text {. }\end{array}$ \\
\hline Rickettsioses & 5-14 days ${ }^{[59]}$ & $\begin{array}{l}\text { Europe, Africa, India, and the Middle } \\
\text { East }^{[59]}\end{array}$ & $\begin{array}{l}\text { Fever, headache, leukopenia, and } \\
\text { thrombocytopenia }{ }^{[59]}\end{array}$ \\
\hline Viral hepatitis & $\begin{array}{l}\text { Hepatitis B: } 60-150 \text { days } \\
\text { Hepatitis C: } 2-22 \text { weeks }\end{array}$ & $\begin{array}{l}\text { Hepatitis B: Countries with medium } \\
\text { to high endemicity (the Middle East, } \\
\text { North Africa, Southeast Asia, South } \\
\text { America, and Central-South Africa) }{ }^{[21]} \\
\text { Hepatitis C: No special region }\end{array}$ & $\begin{array}{l}\text { Fever, headache, malaise, loss of appetite, nausea, } \\
\text { vomiting, jaundice }{ }^{[37]}\end{array}$ \\
\hline Ebola & $2-21$ days $^{[71]}$ & $\begin{array}{l}\text { Congo Republic, Ivory Coast, } \\
\text { Democratic Republic of Congo, Gabon, } \\
\text { Uganda, Guinea, Liberia, and Sierra } \\
\text { Leone }^{[71]}\end{array}$ & $\begin{array}{l}\text { Fever, headache, muscle aches, widespread macular } \\
\text { rash, petechiae, ecchymosis, nausea, vomiting, } \\
\text { diarrhea, and abdominal pain. Thrombocytopenia, } \\
\text { leukopenia, elevated liver enzymes }{ }^{[7]]}\end{array}$ \\
\hline Lyme & $3-30$ days $^{[82]}$ & Italy, Spain, Greece, Russia, China ${ }^{[82]}$ & $\begin{array}{l}\text { Fever, headache, malaise, arthralgia, and myalgia; } \\
\text { erythema migrans }{ }^{[82]}\end{array}$ \\
\hline MERS-CoV & 2-14 days & $\begin{array}{l}\text { Countries on the Arabian peninsula, } \\
\text { England, Germany, France, Greece, } \\
\text { Italy, Tunisia, Malaysia, the Philippines, } \\
\text { the USA, the Netherlands, Turkey, } \\
\text { China, Thailand, and South Korea }{ }^{[89]}\end{array}$ & $\begin{array}{l}\text { Fever, cough, shortness of breath, hemoptysis, } \\
\text { myalgia, diarrhea, abdominal pain }{ }^{[89]}\end{array}$ \\
\hline Leptospirosis & 2-30 days & $\begin{array}{l}\text { South Asia, Oceania, the Caribbean, } \\
\text { sub-Saharan Africa }{ }^{[3]}\end{array}$ & $\begin{array}{l}\text { Fever, headache, myalgia, conjunctival suffusion, } \\
\text { and jaundice }{ }^{[79]}\end{array}$ \\
\hline
\end{tabular}

MERS-CoV: Middle East respiratory syndrome-coronavirus

destination, it is generally malaria. $P$. falciparum is responsible for the majority of malaria deaths ${ }^{[3]}$. Focusing on lifethreatening, infectious, and treatable diseases is important for public health ${ }^{[61]}$. Travel-related febrile illnesses are summarized in Table 5.

\section{Malaria}

Malaria is the most common cause of travel-related systemic febrile illness. It should be considered first in patients with history of travel to sub-Saharan Africa or Southeast Asia. Thick and thin peripheral blood smears should be performed without delay. The smears should be repeated if initial results are negative. At least three negative smears are required to rule out malaria ${ }^{[61]}$.

$P$. falciparum is responsible for $90 \%$ of malaria cases in subSaharan Africa. Symptoms generally appear within one month.
The disease is easily cured if treated early; however, mortality in patients who develop organ failure is around 20\% despite appropriate treatment. $P$. vivax is the infecting agent in more than $70 \%$ of the travelers returning from Asia and Latin America, and only $50 \%$ of these patients begin showing symptoms within 1 month. $P$. vivax and $P$. ovale may reappear weeks or even months after the primary infection due to hypnozoites remaining dormant in the liver ${ }^{[61]}$.

Although fever is the most common symptom, it may not be present in $10-40 \%$ of cases $^{[62]}$. The clinical presentation primarily characterized by fever and nonspecific symptoms is referred to as 'symptomatic malaria'. 'Complicated malaria' manifests with high levels of parasitemia (>5\% of erythrocytes in blood smear) accompanied by clinical or laboratory findings of organ failure. Signs and symptoms may include changes in consciousness, reduced oral intake, seizures, dyspnea, tachypnea, vascular 
collapse, hepatitis, hemoglobinuria, abnormal spontaneous hemorrhage, acute renal failure, pulmonary edema (radiological), hepatosplenomegaly, and petechiae. Complicated malaria is usually associated with $P$. falciparum ${ }^{[63]}$.

Malaria caused by $P$. ovale, $P$. vivax, and $P$. malaria can be treated on an outpatient basis in patients with no other comorbidities or regular medications. All patients diagnosed with $P$. falciparum and patients with undetermined mixed-species infections should be hospitalized. Multidrug-resistant $P$. falciparum should be treated for at least 48 hours. Complicated malaria requires urgent treatment with full-dose parenteral antimalarial therapy ${ }^{[62]}$. Detailed treatment guidelines are available in the updated WHO and CDC recommendations ${ }^{[56,57]}$.

There are no TRI surveillance programs in Turkey. According to Public Health Institution of Turkey (PHIT) surveillance data for vectorborne diseases, there were 208 imported malaria cases in 2016, 58\% of which were caused by $P$. falciparum and $22 \%$ by $P$. vivax. Four of the 208 malaria cases were fatal. Between 2010 and 2016, there were a total of 1,284 imported malaria cases. The agents most commonly originated from Sudan (186), Nigeria (137), Equatorial Guinea (93), and Uganda (69).

In every city in Turkey, an officer of the Department of Malaria Control of the Ministry of Health is on duty for 7 days/24 hours. These officers provide treatment to patients. Malaria treatment is summarized in Table 6.

\section{Dengue}

Dengue virus belongs to the Flavivirus family and has four serotypes. It is transmitted by the daytime bites of the Aedes aegypti mosquito. WHO has classified dengue infections into four clinical types: fever of unknown origin or viral syndrome, classic dengue fever, dengue hemorrhagic fever (DHF), and dengue shock syndrome (DSS). Infections are mostly (75\%) asymptomatic or progress as simple febrile illness ${ }^{[64]}$. Dengue hemorrhagic fever and DSS usually develop in individuals with previous exposure to the virus and have antibodies in their

Table 6. Malaria treatment ${ }^{[57]}$

\begin{tabular}{|c|c|c|}
\hline & $\begin{array}{l}\text { Malaria species / chloroquine } \\
\text { susceptibility }\end{array}$ & Treatment \\
\hline \multirow[t]{10}{*}{ Uncomplicated malaria } & \multirow[t]{4}{*}{$\begin{array}{l}\text { P. falciparum or unidentified species } \\
\text { (chloroquine-resistant or unknown) }\end{array}$} & $\begin{array}{l}\text { Combination tablet ( } 250 \mathrm{mg} \text { atovaquone and } 100 \mathrm{mg} \text { proguanil) oral, } 4 \\
\text { tablets once daily ( } 3 \text { days) }\end{array}$ \\
\hline & & $\begin{array}{l}\text { Combination tablet ( } 20 \mathrm{mg} \text { artemether and } 120 \mathrm{mg} \text { lumefantrine) oral, } \\
\text { first day } 4 \text { tablets initially and } 8 \mathrm{hr} \text { later } 4 \text { tablets, second and third day } 4 \\
\text { tablets twice daily }\end{array}$ \\
\hline & & $\begin{array}{l}\text { Quinine sulfate ( } 650 \mathrm{mg} \text { salt) } 3 \text { times daily ( } 3-7 \text { days) + doxycycline } 100 \\
\mathrm{mg} \text { twice daily ( } 7 \text { days) / tetracycline } 250 \mathrm{mg} 4 \text { times daily ( } 7 \text { days } / \\
\text { clindamycin } 600 \mathrm{mg} \text { twice daily ( } 7 \text { days) }\end{array}$ \\
\hline & & Mefloquine $1250 \mathrm{mg}$ once daily / $750 \mathrm{mg}+500 \mathrm{mg} 8$ hours later \\
\hline & \multirow[t]{2}{*}{ Chloroquine-sensitive $P$. falciparum } & $\begin{array}{l}\text { Chloroquine phosphate } 600 \mathrm{mg} \text { initially }+300 \mathrm{mg} \mathrm{6,} \mathrm{24,} \mathrm{and} 48 \text { hours } \\
\text { later }\end{array}$ \\
\hline & & 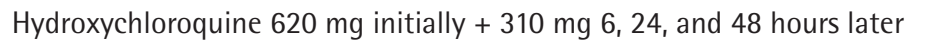 \\
\hline & \multirow[t]{2}{*}{$\begin{array}{l}\text { Chloroquine-sensitive P. malaria/P. } \\
\text { knowlesi }\end{array}$} & $\begin{array}{l}\text { Chloroquine phosphate } 600 \mathrm{mg} \text { initially }+300 \mathrm{mg} \mathrm{6,} \mathrm{24,} \mathrm{and} 48 \text { hours } \\
\text { later }\end{array}$ \\
\hline & & 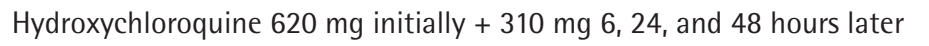 \\
\hline & Chloroquine-sensitive $P$. vivax/P. ovale & $\begin{array}{l}\text { Because of hypnozoites, chloroquine / hydroxychloroquine + primaquine } \\
\text { phosphate } 30 \mathrm{mg} / \text { day ( } 14 \text { days) }\end{array}$ \\
\hline & Chloroquine-resistant $P$. vivax & $\begin{array}{l}\text { Resistant } P \text {. falciparum therapy + primaquine phosphate } 30 \text { mg/day (14 } \\
\text { days) }\end{array}$ \\
\hline \multirow{3}{*}{$\begin{array}{l}\text { Uncomplicated malaria } \\
\text { pregnant women }\end{array}$} & Chloroquine-sensitive & Chloroquine-sensitive $P$. falciparum therapy \\
\hline & \multirow[t]{2}{*}{ Chloroquine-resistant } & $\begin{array}{l}\text { Quinine sulfate ( } 650 \mathrm{mg} \text { salt) } 3 \text { times daily ( } 3-7 \text { days) + clindamycin } 600 \\
\mathrm{mg} \text { twice daily ( } 7 \text { days) }\end{array}$ \\
\hline & & Mefloquine $1250 \mathrm{mg}$ once daily / $750 \mathrm{mg}+500 \mathrm{mg} 8$ hours later \\
\hline \multirow[t]{2}{*}{ Complicated malaria } & \multirow[t]{2}{*}{ All malaria cases } & $\begin{array}{l}\text { Quinidine gluconate [10 mg salt } / \mathrm{kg} \text { loading dose (maximum } 600 \mathrm{mg} \text { ) IV } \\
\text { over } 1-2 \text { hours, followed by } 0.02 \mathrm{mg} / \mathrm{kg} / \mathrm{min} \text { infusion until patient can } \\
\text { tolerate oral intake] + doxycycline / tetracycline / clindamycin (pregnant } \\
\text { women) }\end{array}$ \\
\hline & & $\begin{array}{l}\text { Artesunate initially, followed by atavaquone-proguanil / clindamycin / } \\
\text { mefloquine }\end{array}$ \\
\hline
\end{tabular}


blood. Five percent of all dengue patients develop severe, lifethreatening disease. The risk of mortality is high if treatment is not initiated immediately after diagnosis. When started early, supportive treatment may reduce the risk of death from 10\% to less than $1 \%{ }^{[65]}$. Dengue fever is widespread in Southeast Asia, the South Pacific, Central America, and the Caribbean. A study of European travelers with dengue fever between 1999 and 2002 revealed that history of travel to Southeast Asia was the most common ${ }^{[66]}$. Although cases occur throughout the year, the incidence is higher in years with heavy rainfal[ ${ }^{[64]}$.

Dengue infection manifests after an incubation period of 4-7 days with influenza-like illness, fever, headache, and muscle pain. Approximately half of patients exhibit lymphadenopathy, diffuse erythema, and maculopapular and petechial rash. Specific findings are leukopenia and thrombocytopenia ${ }^{[67]}$. The most severe forms of the disease are DHF and DSS. However, these forms are rarely seen in travelers. Diagnosis is based on the patient's history, clinical findings, and serologic tests (detection of $\lg \mathrm{M}$ and $\lg \mathrm{G}$ ). Treatment consists of nonspecific supportive therapy ${ }^{[67]}$.

According to the data from the PHIT, there were 1, 4, 5, 3, and 12 dengue cases, respectively in the years 2013-2017. The only dengue-related fatality in Turkey was reported in 2014.

\section{Chikungunya}

Chikungunya is an important differential diagnosis for dengue fever in travelers returning from endemic regions. The Chikungunya virus is a mosquitoborne alphavirus. It is common in India, Southeast Asia, and South Africa. The disease may follow an acute, subacute, or chronic course. About 50\% of patients exhibit an itchy macular or maculopapular rash. Articular symptoms are more pronounced compared to dengue fever. Subacute Chikungunya appears approximately two to three weeks after exposure to the agent. Symptoms include distal polyarthritis, malaise, fatigue, and depression. Arthralgia lasts longer than three months in chronic Chikungunya. Chronic infection is more common among individuals over 45 years of age, those with a history of chronic joint disorders, and those with severe acute disease. Real-time-polymerase chain reaction (RT-PCR) is the most sensitive and rapid method of diagnosis. There is no specific antiviral treatment ${ }^{[62]}$.

According to data from the PHIT, there have been two cases of Chikungunya in Turkey, one in 2013 and one in 2016.

\section{Zika}

Zika virus is transmitted via the bite of Aedes mosquitoes, species which also spread dengue and Chikungunya ${ }^{[37]}$. Other routes of transmission are intrauterine, perinatal, sexual, laboratory, and transfusion. The zika virus belongs to the Flavivirus family. Patients exhibit symptoms such as fever, maculopapular rash, arthralgia, and conjunctivitis within two weeks of travel to regions with risk of infection. These symptoms appear in approximately $20 \%$ of the infected patients ${ }^{[68]}$. The disease is self-limiting and resolves in 2-7 days, usually with no need for hospitalization. Treatment is symptomatic, including rest, hydration, and reducing pain and fever ${ }^{[37]}$. Mortality and morbidity rates are low, but the fetus of an infected pregnant woman may develop microcephaly and other congenital brain anomalies. The CDC advises pregnant women to avoid travel to areas of risk. The male partner of a pregnant woman should use condoms during sex or avoid sex (vaginal, anal, or oral) for the duration of the pregnancy if he has traveled to a region with zika $^{[68]}$.

\section{Viral Hemorrhagic Fever (VHF)}

The risk of VHF is very low for travelers. Travelers with a higher risk of disease are those engaging in animal research, health workers, and patient caregivers. It is important because, if not detected, it may be transmitted to laboratory personnel and patient caregivers. There is no specific treatment for these diseases, and mortality is high ${ }^{[69]}$.

Crimean-Congo hemorrhagic fever (CCHF) has caused epidemics in Turkey, Russia, Iran, Pakistan, and Afghanistan over the last 15 years. It is a zoonotic disease primarily transmitted through tick contact. Main symptoms are malaise, fever, myalgia, headache, and mucosal hemorrhage. Laboratory findings include elevated liver enzymes, thrombocytopenia, and leukopenia. The differential diagnosis includes malaria, dengue, leptospirosis, and rickettsiosis. A literature search for travel-related CCHF resulted in 21 cases, four of which resulted from nosocomial transmission ${ }^{[70]}$.

Ebola is a VHF that is transmitted by droplet transmission and/ or direct contact. It is seen in Zaire (Democratic Republic of the Congo), Sudan, the United Kingdom, the Philippines, the USA, Gabon, the Ivory Coast, Russia, and Uganda ${ }^{[7]}$. Main symptoms are fever, headache, muscle pain, widespread macular rash, petechiae, ecchymosis, nausea, vomiting, diarrhea, and abdominal pain. Laboratory findings include leukopenia, thrombocytopenia, and elevated liver enzymes. The casemortality ratio is $70.8 \%$. Despite having such a high mortality rate, there is no effective treatment or vaccine for Ebola. Therefore, early diagnosis and patient isolation are critical in order to control epidemics ${ }^{[72]}$. To date, Ebola has not been reported in Turkey.

\section{Enteric Fever}

Enteric fever is a bacterial systemic illness caused by Salmonella enterica serovar typhi or Salmonella enterica serovars paratyphi $A, B$, and $C$. Transmission occurs via fecal-oral route in countries with poor hygienic conditions. In a study by Wilson et al. ${ }^{[66]}$, 
analysis of data from the GeoSentinel Surveillance Network revealed that it accounted for $2 \%$ of all fevers in returned travelers. The incidence of enteric fever has significantly fallen in developed countries over the last century. It has become mainly a travel-related disease. The risk varies depending on the destination, though a history of travel to India is most common among affected travelers. The incidence of disease caused by S. paratyphi is higher among travelers to endemic countries. Incubation lasts about 7-14 days and the initial symptoms are fever and malaise. Other symptoms include influenza-like illness, frontal headache, nausea, and vomiting. Patients may exhibit hepatosplenomegaly, rose spots on the chest and abdomen, and relative bradycardia. Encephalopathy and gastrointestinal hemorrhage and perforation are very rare complications. The mortality rate is $30 \%$ in endemic countries, compared to $0.4 \%$ in travelers ${ }^{[73]}$. Antimicrobial treatment reduces the duration of symptoms. Fluoroquinolones are suggested as empirical treatment, but resistance to plasmid-mediated fluoroquinolone is becoming increasingly common. Azithromycin and thirdgeneration cephalosporins should be preferred in South and Southeast Asia because of high quinolone resistance ${ }^{[4]}$. Treatment includes ciprofloxacin (500 mg orally twice daily or $400 \mathrm{mg}$ IV twice daily) for 7-10 days, azithromycin (oral; single $1000 \mathrm{mg}$ dose day 1 followed by $500 \mathrm{mg}$ once daily for 5-7 days), and ceftriaxone (2 g IV once daily) for 7-14 days ${ }^{[74]}$.

\section{Rickettsioses}

Rickettsioses are acute zoonotic infections caused by obligate intracellular Gram-negative bacteria. They are transmitted by ticks, mites, and lice. The bacterial agents may be categorised in four subgroups: Rickettsia (subdivided into the spotted fever and typhus groups), Orientia, Ehrlichia, and Anaplasma. Studies have shown rickettsioses account for $0.5-2 \%$ of febrile illnesses, and almost $20 \%$ require hospitalization ${ }^{[4]}$.

The most commonly detected travel-related rickettsioses are Mediterranean spotted fever, caused by Rickettsia conorii and Rickettsia africae, and scrub typhus, caused by Orientia tsutsugamushi. After malaria, R. africae is the second most common cause of fever in travelers to Africa ${ }^{[75]}$. Patients may have fever, headache, leukopenia, and thrombocytopenia. Rickettsioses cause widespread vasculitic lesions. Although these lesions are pathognomonic, malaria must be included in the differential diagnosis and should be investigated via thick and thin blood smears. Diagnosis is based on immunofluorescent antibody (IFA) assay, PCR, and Western blot. A 4-fold increase in $\lg \mathrm{G}$ or IgM titer in IFA assays of serum samples taken at an interval of ten days is considered significant. If the clinical findings are consistent with the patient's history, treatment with doxycycline or tetracycline should be initiated without waiting for laboratory confirmation ${ }^{[76]}$. Doxycycline should be administered orally as $100 \mathrm{mg}$ twice daily for 7 days $^{[74]}$.

\section{Viral Hepatitis}

Acute viral hepatitis begins suddenly with fever, malaise, nausea, and stomach discomfort, followed by the development of jaundice within a few days. Hepatitis $A$ and $E$ are transmitted through close contact with infected persons and consuming contaminated food and water. Hepatitis B is transmitted through percutaneous injuries and unprotected sexual intercourse. Acupuncture, tattoos, and other procedures that break the skin are potentially risky. It may pass from mother to baby during pregnancy ${ }^{[4]}$. Treatment is not recommended for acute hepatitis B. Only severe clinical cases may require hospitalization and supportive treatment ${ }^{[77]}$. Hepatitis $\mathrm{C}$ is usually transmitted through injection using contaminated needles and syringes. Most acute HCV infections are asymptomatic. Hepatitis develops in less than 25\% of infections. Spontaneous clearance occurs in two-thirds of infected patients. Treatment is required if HCV RNA positivity persists after six months ${ }^{[78]}$. The incidence of hepatitis $A$ and $B$ have fallen over time due to pretravel consultation and routine immunization ${ }^{[45]}$.

\section{Leptospirosis}

Leptospira interrogans is the infectious agent. Mice and farm animals are natural carriers of this bacteria. It is transmitted through skin and mucosal contact with water contaminated with the urine of infected animals and via consumption of contaminated water and food. In addition to nonspecific symptoms such as fever, headache, and myalgia in the proximal lower extremities, conjunctival suffusion and jaundice are more common in leptospirosis than other febrile illnesses. Southeast Asia is the most common destination among infected travelers ${ }^{[3]}$. In a study by Jensenius et al. ${ }^{[79]}$ regarding life-threatening acute TRIs, leptospirosis accounted for $10 \%$ of the cases, $50 \%$ of which required hospitalization. Mild to moderate cases may be treated with oral doxycycline $100 \mathrm{mg}$ twice daily for 5-7 days or oral amoxicillin $500 \mathrm{mg}, 3$ times daily for 7 days. Severe disease is treated with IV crystallized penicillin, 1.5 million units 4 times daily for 7 days ${ }^{[80]}$.

\section{Lyme}

Lyme disease is caused by Borrelia burgdorferi and transmitted by Ixodes spp. ticks, and presents as fever with rash ${ }^{[81]}$. An erythema migrans lesion with a pale center surrounded by a red ring often forms around the site of the tick bite. Symptoms may include fever, headache, malaise, arthralgia, and myalgia. If not treated, it may lead to neurological and cardiac problems. Treatment consists of oral doxycycline $100 \mathrm{mg}$ twice daily for 10 days and oral amoxicillin $500 \mathrm{mg} 3$ times daily for 14 days ${ }^{[82]}$.

\section{Traveler's Diarrhea}

Traveler's diarrhea involves passing loose and watery stools for 3 or more times within 24 hours. It may not be accompanied 
by other symptoms such as nausea, vomiting, tenesmus, and fever. South Asia and Western/Central Africa are the regions of highest risk for traveler's diarrhea ${ }^{[59]}$.

Studies have determined gastrointestinal infections to be responsible for approximately $34 \%$ of morbidity. However, economic development and improved hygienic conditions have reduced the frequency over time ${ }^{[83]}$.

More than $40 \%$ of the diarrhea cases are acute diarrheal syndrome. The causative agent is usually bacteria. The most common diarrhea agents are ETEC, Enteroaggregative E. coli, neuroviruses, rotavirus, Salmonella spp., Shigella spp., Campylobacter jejuni, Aeromonas spp., Plesiomonas shigelloides, Bacteroides fragilis, and Vibrio spp. Parasitic agents include Giardia duodenalis, Cryptosporidium spp., Entamoeba histolytica, and Microsporidium spp. ${ }^{[59]}$.

Although ETEC is the most common agent in general, Campylobacter and Aeromonas are more prevalent in Southeast Asia, including Thailand. Like invasive bacterial agents, parasitic agents may also cause prolonged diarrhea and are more common in extended travel ${ }^{[59]}$.

Long-term complications may occur following diarrhea. Postinfectious irritable bowel syndrome develops in $3-17 \%$ of patients. Postinfectious irritable bowel syndrome is associated with factors such as the severity of acute diarrhea, the number of episodes, infection with ETEC, pretravel diarrhea, and poor living conditions ${ }^{[59]}$.

Travelers should be informed on about traveler's diarrhea. Individuals with mild diarrhea (daily activities are not hindered and stool is passed up to three times a day) should be able to treat themselves. Preventing dehydration is important. Instead of antibiotics, loperamide or bismuth compounds should be taken initially to reduce bowel movements. Quinolones are generally a good treatment option; however, azithromycin should be preferred in travel to South/Southeast Asia since $C$. jejuni is the most common cause of diarrhea in these regions. Rifaximin may also be considered in suspected cases of noninvasive diarrhea. One to three days of treatment is sufficient. Laboratory tests should be done in cases of diarrhea that presents with $39{ }^{\circ} \mathrm{C}$ fever, lasts longer than 14 days, or is accompanied by choleralike dehydration symptoms ${ }^{[59]}$.

\section{Dermatological Diseases}

Dermatological diseases account for approximately $10 \%$ of travelrelated diseases, about 10\% of which require hospitalization. Approximately 50\% of dermatological diseases are related to infection. It should be kept in mind that dermatoses tend to develop more often and progress more rapidly in hot climates due to increased perspiration and secretion. Travelers to tropical regions are exposed to more bugs and contaminated soil and water compared to regions with a mild climate. This increases the frequency of skin-related health problems ${ }^{[4]}$.

Arthropod bites are extremely common. They are responsible for $10 \%$ of dermatoses associated with travel to tropical regions and for 15-18\% of global travel-related dermatoses. Patients may develop papules, nodules, or ulcerated lesions with eschar ${ }^{[84]}$.

Bacterial skin lesions may manifest also as impetigo (Staphylococcus aureus and Streptococcus spp.), folliculitis, ecthyma, erysipelas, abscess, or necrotizing cellulitis ${ }^{[84]}$.

Dermatological conditions may also occur in the course of systemic febrile illnesses. For example, maculopapular rash may be seen in dengue, Chikungunya, schistosomiasis, and rickettsioses. Dengue fever may be accompanied by widespread erythema, petechiae, and ecchymotic lesions. Ecchymotic lesions may also be seen in leptospirosis, meningococcal infections, and rickettsial infections. The characteristic skin lesion of $R$. africae is the black eschar at the inoculation site ${ }^{[84]}$.

About 85\% of all schistosomiasis cases worldwide occur on the continent of Africa. Schistosomes may infect the urinary system (S. hematobium) or intestinal system. It occurs a few hours after cercaria in fresh water attach to and penetrate the skin and causes an itchy papular rash which usually lasts less than 48 hours. This is followed by a widespread, itchy, creeping rash on the body ${ }^{[84]}$. A case of urinary schistosomiasis was reported in Turkey, but the patient was a Nigerian citizen who was in Turkey when symptoms appeared ${ }^{[85]}$.

Cutaneous leishmaniasis (CL) is one of the most common travelrelated dermatoses. Almost 90\% of cases worldwide are from Afghanistan, Algeria, Brazil, Peru, Saudi Arabia, Iran, Iraq, and Syria. Various skin lesions may be present. There may be papules, plaques, and nodules progressing as far as ulceration. Painless ulcer is a classic finding of CL. Ulcerative lesions may also be seen in pyoderma, mycobacterial and deep fungal infections ${ }^{[84]}$.

Cutaneous larva migrans is a dermatosis caused by hookworms. It is more commonly seen in people coming from sub-Saharan Africa, Asia, South America, and the Caribbean (most widespread in Brazil, Jamaica, Malaysia, and Thailand). It is transmitted through the skin via direct contact with a contaminated surface. It usually affects the legs due to walking barefoot on beaches or sandy soil. The rash begins as linear redness about $3 \mathrm{~mm}$ wide and 15-20 mm long, and may extend by up to a few centimeters per day. It develops into itchy papules or vesiculobullous rash in $15 \%$ of cases. Itching is localized to the area of eruption. There are 1 to 3 lesions on average, as in CL. Vesicles and bullae may also occur due to sunburn, contact dermatitis, arthropod bite, impetigo, and herpes infections ${ }^{[84]}$. 
Strongyloidiasis is a skin infection caused by the nematode Strongyloides stercoralis and has a higher prevalence in tropical and subtropical regions. The larvae penetrate healthy skin. Gastrointestinal (abdominal pain, diarrhea), pulmonary (Löffler syndrome), and cutaneous manifestations appear as the parasite migrates through the host body. One of the cutaneous manifestations is an itchy, linear, advancing rash occurring mostly around the anus and on the body (larva currens). Cutaneous lesions resolve within hours or days but later recur. Another cutaneous manifestation is urticarial rash. It mainly appears around the hips and lower back, resolves after one or two days, and may recur at regular intervals.

Skin lesions move around the body in both cutaneous larva migrans and strongyloidiasis ${ }^{[86]}$.

Loasis is a parasitic infection seen in Western and Central Africa. It is transmitted by bloodsucking flies. Most infections are asymptomatic. The most common symptoms are recurrent subcutaneous soft tissue swellings (Calabar swellings) and chronic itching ${ }^{[86]}$.

\section{Respiratory Tract Infections}

The most common travel-related respiratory tract infections are streptococcal pharyngitis, sinusitis, otitis, influenza, pneumonia, and bronchitis. Respiratory tract symptoms may also occur in schistosomiasis, strongyloidiasis, hookworm infestations, leptospirosis, and $\mathrm{Q}$ fever $^{[4]}$.

Respiratory tract infections comprise $10-20 \%$ of all TRIs, and lower respiratory tract infections account for about 35\% of them ${ }^{[87]}$.

In their study on travel-related respiratory tract infections, Leder et al. ${ }^{[87]}$ found that advanced age and male gender were risk factors for lower respiratory tract infections. They also determined that the purpose and season of travel were associated with the incidence of TRIs. Travelers facing the greatest risk were those traveling to the northern hemisphere between December and February and those visiting relatives for longer than 30 days.

In a study on TRls between 2007 and 2011 conducted using GeoSentinel data, it was reported that 28 patients died, 9 of whom had lower respiratory tract infections ${ }^{[4]}$.

Respiratory tract infections are the most common diseases seen in cruise ship epidemics. Influenza is one of the most common vaccine-preventable diseases. The main risk factors for Legionella pneumophila, an atypical pneumonia agent, were history of travel in the last 2 weeks, staying in hotels with air conditioning, activities such as visiting spa, using sauna, and traveling on cruise ships ${ }^{[87]}$. There are reports from Turkey of imported cases of infection caused by various $L$. pneumophila serotypes in patients with history of travel to Iraq and staying at hotels ${ }^{[88]}$.

Middle East respiratory syndrome-coronavirus causes severe lower respiratory tract infections in humans. The majority (85\%) of cases occur in Saudi Arabia, but it is also reported in England, Germany, France, Greece, Italy, Tunisia, Malaysia, the Philippines, the USA, the Netherlands, Turkey, China, Thailand, and South Korea. A case of Saudi Arabian origin has been reported in Turkey. The importance of this disease among TRI is that there is no specific treatment, it spreads via respiratory transmission, has high mortality, and may cause hospital-based epidemics if not detected ${ }^{[89]}$.

\section{Conclusion}

There is a steady increase in international travel for various reasons such as business trips, vacation, missionary activities, family visits, and long-term employment. As the geographic distribution of diseases is dynamic, affected by ecologic, genetic, and human factors, travel results in pathogens being introduced to new regions and populations. Approximately $22-64 \%$ of travelers experience health problems ${ }^{[3]}$. Most of these are self-limiting diseases ${ }^{[4,5]}$. However, life-threatening conditions that require rapid diagnosis and immediate treatment or patient isolation must also be kept in mind, such as malaria, dengue, yellow fever, Lassa fever, leptospirosis, typhus, Ebola, and enteric fever. The clinician should bear in mind two lists of prediagnoses, one list of diseases that may cause these clinical symptoms under normal conditions (such as meningitis, pneumonia) and the other list of travel-related diseases (such as malaria, schistosomiasis) ${ }^{[3]}$.

The CDC travel health website advises persons planning to visit Turkey as tourists, to complete any missing hepatitis A and B vaccinations and recommends typhus vaccination if planning to visit rural areas or relatives and rabies vaccination for veterinarians with high occupational exposure to animals or tourists planning to participate in extreme/adventure sports. The site also reports that 7,000 measles cases were reported in Turkey in 2013 and this poses a low-level risk for tourists ${ }^{[21]}$.

There is no national TRI data for Turkey other than case reports in the literature. Clinicians in each branch can collect clinical data relevant to their specialty in a surveillance network and the results can be presented as annual data. Surveillance systems are needed to determine the most common agents in the destination countries and their treatment resistance status. Furthermore, asking patients presenting to emergency services about their travel history must not be overlooked. The Turkish Ministry of Health has established a 'Traveler's Health' website that provides information about risk factors, required vaccinations, and necessary prophylaxis according to destination. Travelers can also 
consult the THCs operated by the Directorate General of Health Services for Borders and Coasts of Turkey ${ }^{[45]}$.

\section{Ethics}

Peer-review: Externally and internally peer-reviewed.

\section{Authorship Contributions}

Concept: H.B., Data Collection or Processing: F.P., E.A., H.B., Analysis or Interpretation: H.B., Literature Search: F.P., Writing: F.P., E.A., H.B.

Conflict of Interest: No conflict of interest was declared by the authors.

Financial Disclosure: The authors declared that this study received no financial support.

\section{References}

1. The World Tourism Organization. Last accessed date: 30 October 2017. Available from: http://fac.ksu.edu.sa/sites/default/files/tourism_ highlights_2016-_unwto.pdf

2. Türkiye İstatistik Kurumu. Last accessed date: 30 October 2017. Available from: http://www.tuik.gov.tr/PreTablo.do?alt_id=1051

3. Steffen $R$, deBernardis C, Banos A. Travel epidemiology-a global perspective. Int J Antimicrob Agents. 2003;21:89-95.

4. Leder K, Torresi J, Libman MD, Cramer JP, Castelli F, Schlagenhauf P, WilderSmith A, Wilson ME, Keystone JS, Schwartz E, Barnett ED, von Sonnenburg F, Brownstein JS, Cheng AC, Sotir MJ, Esposito DH, Freedman DO; GeoSentinel Surveillance Network. GeoSentinel surveillance of illness in returned travelers, 2007-2011. Ann Intern Med. 2013;158:456-68.

5. Mendelson $M$, Han PV, Vincent $P$, von Sonnenburg $F$, Cramer JP, Loutan $L$, Kain KC, Parola P, Hagmann S, Gkrania-Klotsas E, Sotir M, Schlagenhauf P; GeoSentinel Surveillance Network. Regional variation in travel-related illness acquired in Africa, March 1997-May 2011. Emerg Infect Dis. 2014;20:532-41.

6. Steffen R, Rickenbach M, Wilhelm U, Helminger A, Schar M. Health problems after travel to developing countries. J Infect Dis. 1987;156:84-91.

7. Freedman DO, Chen LH, Kozarsky PE. Medical considerations before international travel. N Engl J Med. 2016;2016:247-60.

8. World Health Organization (WHO) Travelers Health. Last accessed date: 30 October 2017. Available from: http://www.who.int/topics/travel/en/

9. Committee to advise on Tropical Medicine and Travel. Last accessed date: 30 October 2017. Available from: https://www.cps.ca/en/documents/position/ CATMAT

10. World Health Organization (WHO) Disease Outbreak News. Last accessed date: 30 October 2017. Available from: http://www.who.int/csr/don/en/

11. World Health Organization (WHO) Weekly Epidemiological Record. Last accessed date: 30 October 2017. Available from: ww.who.int/wer/en/

12. CDC Morbidity and Mortality Weekly Report. Last accessed date: 30 October 2017. Available from: https://www.cdc.gov/mmwr/index.html

13. World Health Organization (WHO) Health Topics. Last accessed date: 30 October 2017. Available from: http://www.who.int/topics/en/

14. International Society of Travel Medicine (ISTM). Last accessed date: 30 October 2017. Available from: http://www.istm.org/

15. Seyahat Sağlığı. Last accessed date: 31 October 2017. Available from: http:// www.seyahatsagligi.gov.tr/Site/YetkiliMerkezler
16. Hargarten SW, Baker TD, Guptill K. Overseas fatalities of United States citizen travelers: an analysis of deaths related to international travel. Ann Emerg Med. 1991;20:622-6.

17. LaRocque RC, Rao SR, Tsibris A, Lawton $T$, Anita Barry M, Marano N, Brunette G, Yanni E, Ryan ET. Pre-travel health advice-seeking behavior among US international travelers departing from Boston Logan International Airport. J Travel Med. 2010;17:387-91.

18. Steffen R, Banos A, deBernardis C. Vaccination priorities. Int J Antimicrob Agents. 2003;21:175-80.

19. Schlagenhauf $P$, Weld $L$, Goorhuis $A$, Gautret $P$, Weber $R$, von Sonnenburg $F$, Lopez-Vélez R, Jensenius M, Cramer JP, Field VK, Odolini S, Gkrania-Klotsas E, Chappuis F, Malvy D, van Genderen PJ, Mockenhaupt F, Jaureguiberry S, Smith C, Beeching NJ, Ursing J, Rapp C, Parola P, Grobusch MP; EuroTravNet. Travel-associated infection presenting in Europe (2008-12): an analysis of EuroTravNet longitudinal, surveillance data, and evaluation of the effect of the pre-travel consultation. Lancet Infect Dis. 2015;15:55-64.

20. Selcuk EB, Kayabas U, Binbasioglu H, Otlu B, Bayindir Y, Bozdogan B, Karatas M. Travel health attitudes among Turkish business travellers to African countries. Travel Med Infect Dis. 2016;14:614-20.

21. Centers for Diseases Control and Prevetions (CDC). Last accessed date: 31 October 2017. Available from: https://wwwnc.cdc.gov/travel/destinations/ clinician/none/turkey?s_cid=ncezid-dgmq-travel-single-002

22. Uludağ Üniversitesi Tıp Fakültesi Kulak Burun Boğaz Anabilim Dalı. Last accessed date: 31 October 2017. Available from: http://kbb.uludag.edu.tr/ HB-aractutmasi.htm

23. Türk Hematoloji Derneği Venöz Tromboz Hasta Kılavuzu. Last accessed date: 31 October 2017. Available from: http://www.thd.org.tr/THD_ Halk/?sayfa=venoz_tromboz_hasta_klavuzu

24. Crawford G, Lobo R, Brown G, Macri C, Smith H, Maycock B. HIV, Other BloodBorne Viruses and Sexually Transmitted Infections amongst Expatriates and Travellers to Low-and Middle-Income Countries: A Systematic Review. Int J Environ Res Public Health. 2016;13.

25. Centers for Diseases Control and Prevetions (CDC). Last accessed date: 31 October 2017. Available from: https://wwwnc.cdc.gov/travel/ yellowbook/2018/infectious-diseases-related-to-travel/hiv-infection

26. Korzeniewski K, Juszczak $D$, Jerzemowski J. Skin lesions in returning travellers. Int Marit Health. 2015;66:173-80.

27. Centers for Diseases Control and Prevetions (CDC). Last accessed date: 30 October 2017. Available from: https://wwwnc.cdc.gov/travel/diseases/ routine

28. T.C. Sağlık Bakanlığı Temel Sağlık Hizmetleri Genel Müdürlüğü Genişletilmiş Bağışıklama Programı Genelgesi (Daimi Belge) 2008/14. Last accessed date: 30 October 2017. Available from: http://dosyasb.saglik.gov.tr/ Eklenti/1117,gbpgenelge2008pdf.pdf

29. Erişkin Bağışıklama Rehberi. Türkiye Enfeksiyon Hastalıkları ve Klinik Mikrobiyoloji Kliniği Uzmanlık Derneği Erişkin Bağışıklama Rehberi Çalışma Grubu. 2. Güncelleme. Ankara. Arvin Yayınevi 2016.

30. McLean HQ, Fiebelkorn AP, Temte JL, Wallace GS; Centers for Disease Control and Prevention. Prevention of measles, rubella, congenital rubella syndrome, and mumps, 2013: summary recommendations of the Advisory Committee on Immunization Practices (ACIP). MMWR Recomm Rep. 2013;62:1-34.

31. Centers for Disease Control and Prevention (CDC). Updated recommendations for use of tetanus toxoid, reduced diphtheria toxoid and acellular pertussis (Tdap) vaccine from the Advisory Committee on Immunization Practices, 2010. MMWR Morb Mortal Wkly Rep. 2011;60:13-5.

32. Centers for Diseases Control and Prevetions (CDC). Last accessed date: 30 October 2017. Available from: https://www.cdc.gov/vaccines/pubs/pinkbook/ dip.htm 
33. Fiore $A E$, Wasley $A$, Bell BP. Prevention of hepatitis A through active or passive immunization: recommendations of the Advisory Committee on Immunization Practices (ACIP). MMWR Recommendations and Reports. 2006;55:1-4.

34. Cuthbert JA. Hepatitis A: old and new. Clin Microbiol Rev. 2001;14:38-58.

35. Tosun S. The Changing Viral Hepatitis Epidemiology in our Country. ANKEM Derg. 2013;27:128-34.

36. Prevention of Varicella Recommendations of the Advisory Committee on Immunization Practices (ACIP). Last accessed date: 30 October 2017. Available from: https://www.cdc.gov/mmwr/preview/mmwrhtml/ rr5604a1.htm

37. Grohskopf LA, Sokolow LZ, Broder KR, Walter EB, Bresee JS, Fry AM, Jernigan DB. Prevention and Control of Seasonal Influenza with Vaccines: Recommendations of the Advisory Committee on Immunization Practices - United States, 2017-18 Influenza Season. MMWR Recommendations and Reports. 2017;66;1-20.

38. Centers for Disease Control and Prevetions (CDC). Last accessed date: 30 October 2017. Available from: https://www.cdc.gov/vaccines/hcp/vis/visstatements/hib.html

39. Centers for Diseases Control and Preventions. Last accessed date: 30 October 2017. Available from: https://www.cdc.gov/vaccines/vpd/pneumo/ hcp/who-when-to-vaccinate.html

40. Centers for Disease Control and Prevetion. Last accessed date: 30 October 2017. Available from: https://www.cdc.gov/vaccines/vpd/pneumo/hcp/ about-vaccine.html

41. CDC Travelers' Health Poliomyelitis. Last accessed date: 31 October 2017. Available from: https://wwwnc.cdc.gov/travel/diseases/poliomyelitits

42. T.C. Sağlık Bakanlığı Poliomyelit Eradikasyonu Klinisyen El Kitabı. Last accessed date: 30 October 2017. Available from: https://sbu.saglik.gov.tr/ Ekutuphane/kitaplar/poliomyeliteradikasyonu.pdf

43. Centers for Diseases Control and Prevetions. Last accessed date: 30 October 2017. Available from: https://www.cdc.gov/vaccines/vpd/polio/hcp/ effectiveness-duration-protection.html

44. Centers for Diseases Control and Prevetions (CDC). Last accessed date: 31 October 2017. Available from: https://wwwnc.cdc.gov/travel/ yellowbook/2018/infectious-diseases-related-to-travel/typhoidparatyphoid-fever

45. Seyahat Sağlığı El Kitabı 2. Baskı T.C. Sağlık Bakanlığı Türkiye Hudut ve Sahiller Sağlık Genel Müdürlüğü. Last accessed date: 31 October 2017. Available from: http://www.seyahatsagligi.gov.tr/Content/Documents/ Seyahat_Sagligi_El_Kitabi.pdf

46. Centers for Diseases Control and Prevetions (CDC). Last accessed date: 31 October 2017. Available from: https://wwwnc.cdc.gov/travel/ yellowbook/2018/infectious-diseases-related-to-travel/japaneseencephalitis

47. Centers for Diseases Control and Prevetions (CDC). Last accessed date: 31 October 2017. Available from: https://wwwnc.cdc.gov/travel/ yellowbook/2018/infectious-diseases-related-to-travel/tickborneencephalitis

48. Centers for Diseases Control and Prevetions (CDC). Last accessed date: 31 October 2017. Available from: https://wwwnc.cdc.gov/travel/ yellowbook/2018/infectious-diseases-related-to-travel/cholera

49. World Health Organization (WHO) Last accessed date: 31 October 2017. Available from: http://www.who.int/immunization/cholera_PP_slides_20_ Mar_2010.pdf.

50. Jackson SS, Chen WH. Evidence for CVD 103-HgR as an effective singledose oral cholera vaccine. Future Microbiol. 2015;10:1271-81.

51. Centers for Diseases Control and Prevetions (CDC). Last accessed date: 31 October 2017. Available from: https://wwwnc.cdc.gov/travel/ yellowbook/2018/infectious-diseases-related-to-travel/rabies
52. Centers for Diseases Control and Prevetions (CDC). Last accessed date: 31 October 2017. Available from: https://wwwnc.cdc.gov/travel/ yellowbook/2018/infectious-diseases-related-to-travel/meningococcaldisease

53. T.C. Sağlık Bakanlığı Ankara II Sağlık Müdürlüğü. Last accessed date: 31 October 2017. Available from: http://www.asm.gov.tr/hacAsilama.htm.

54. Centers for Diseases Control and Prevetions (CDC). Last accessed date: 31 October 2017. Available from: https://wwwnc.cdc.gov/travel/ yellowbook/2018/infectious-diseases-related-to-travel/yellow-fever

55. World Health Organization (WHO). Last accessed date: 31 October 2017. Available from: http://www.who.int/immunization/sage/meetings/2013/ april/3_YF_BOOSTER_FINAL_DRAFT2.pdf

56. Centers for Diseases Control and Prevetions (CDC). Last accessed date: 31 October 2017. Available from: https://www.cdc.gov/malaria/travelers/drugs. html

57. World Health Organization (WHO). Last accessed date: 29 Haziran 2017. Available from: http://www.who.int/malaria/en/

58. Freedman D0. Malaria prevention in short-term travelers. N Engl J Med. 2008;359:603-12.

59. Steffen R, Hill DR, DuPont HL. Traveler's diarrhea: a clinical review. JAMA. 2015;313:71-80

60. Erdem H, Ak O, Elaldi N, Demirdal T, Hargreaves $S$, Nemli $S$, Cag Y, Ulug M, Naz H, Gunal O, Sirmatel F, Sipahi OR, Alpat SN, Ertem-Tuncer G, Sozen H, Evlice 0, Meric-Koc M, Dogru A, Koksaldi-Motor V, Tekin R, Ozdemir D, Ozturk-Engin D, Savasci U, Karagoz E, Cekli Y, Inan A. Infections in travellers returning to Turkey from the Arabian peninsula: a retrospective crosssectional multicenter study. Eur J Clin Microbiol Infect Dis. 2016;35:903-10.

61. Ryan ET, Wilson ME, Kain KC, O'Brien D, Tobin S, Brown G, Torresi J, Caumes E, Carriere J, Guermonprez G. Illness after international travel. N Engl J Med. 1984;2002:2002.

62. Wattal C, Goel N. Infectious disease emergencies in returning travelers: special reference to malaria, dengue fever, and Chikungunya. Med Clin North Am. 2012;96:1225-55.

63. Dorsey G, Gandhi M, Oyugi JH, Rosenthal PJ. Difficulties in the prevention, diagnosis, and treatment of imported malaria. Arch Intern Med. 2000;160:2505-10.

64. Wichmann 0, Jelinek T. Dengue in travelers: a review. J Travel Med. 2004; 11:161-70.

65. Centers for Diseases Control and Prevetions (CDC). Last accessed date: 31 October 2017. Available from: https://wwwnc.cdc.gov/travel/ yellowbook/2018/infectious-diseases-related-to-travel/dengue

66. Wilson ME, Weld LH, Boggild A, Keystone JS, Kain KC, Von Sonnenburg $F_{\text {, }}$ Schwartz E; GeoSentinel Surveillance Network. Fever in returned travelers: results from the GeoSentinel Surveillance Network. Clin Infect Dis. 2007;44:1560-8.

67. World Health Organization (WHO). Dengue: Guidelines for diagnosis, treatment, prevention and control 2009 Last accessed date: 29 Haziran 2017. Available from: http://www.who.int/tdr/publications/documents/dengue-diagnosis.pdf

68. Centers for Diseases Control and Prevetions (CDC). Last accessed date: 31 October 2017. Available from: https://wwwnc.cdc.gov/travel/ yellowbook/2018/infectious-diseases-related-to-travel/zika

69. Centers for Diseases Control and Prevetions (CDC). Last accessed date: 31 October 2017. Available from: https://wwwnc.cdc.gov/travel/ yellowbook/2018/infectious-diseases-related-to-travel/viral-hemorrhagicfevers

70. Leblebicioglu H, Ozaras R, Fletcher TE, Beeching NJ; ESCMID Study Group for Infections in Travellers and Migrants (ESGITM). Crimean-Congo haemorrhagic fever in travellers: a systematic review. Travel Med Infect Dis. 2016;14:73-80. 
71. Feldmann H, Geisbert TW. Ebola haemorrhagic fever. Lancet. 2011;377:84962.

72. Baştuğ $A$, Bodur H. Ebola viral disease: What should be done to combat the epidemic in 2014? Turk J Med Sci. 2015;45:1-5.

73. Connor BA, Schwartz E. Typhoid and paratyphoid fever in travellers. Lancet Infect Dis. 2005;5:623-8.

74. Sanford Guide Last accessed date: 31 October 2017. Available from: https:// www.sanfordguide.com/

75. Korzeniewski K, Gaweł B, Krankowska D, Wasilczuk K. Fever of unknown origin in returning travellers. Int Marit Health. 2015;66:77-83.

76. Jensenius $M$, Davis $X$, Von Sonnenburg F, Schwartz E, Keystone JS, Leder K, Lopéz-Véléz R, Caumes E, Cramer JP, Chen L; GeoSentinel Surveillance Network. Multicenter GeoSentinel analysis of rickettsial diseases in international travelers, 1996-2008. Emerg Infect Dis. 2009;15:1791-8.

77. Centers for Diseases Control and Prevetions (CDC). Last accessed date: 31 October 2017. Available from: https://wwwnc.cdc.gov/travel/ yellowbook/2018/infectious-diseases-related-to-travel/hepatitis-b

78. Centers for Diseases Control and Prevetions (CDC). Last accessed date: 31 October 2017. Available from: https://wwwnc.cdc.gov/travel/ yellowbook/2018/infectious-diseases-related-to-travel/hepatitis-c

79. Jensenius $M$, Han PV, Schlagenhauf $P$, Schwartz $E$, Parola $P$, Castelli $F$, von Sonnenburg F, Loutan L, Leder K, Freedman D0; GeoSentinel Surveillance Network. Acute and potentially life-threatening tropical diseases in western travellers-a GeoSentinel multicenter study, 1996-2011. Am J Trop Med Hyg. 2013;88:397-404.

80. Centers for Diseases Control and Prevetions (CDC). Last accessed date: 31 October 2017. Available from: https://wwwnc.cdc.gov/travel/ yellowbook/2018/infectious-diseases-related-to-travel/leptospirosis
81. Schotthoefer AM, Frost HM. Ecology and Epidemiology of Lyme Borreliosis. Clin Lab Med. 2015;35:723-43.

82. Wormser GP, Dattwyler RJ, Shapiro ED, Halperin JJ, Steere AC, Klempner MS, Krause PJ, Bakken JS, Strle F, Stanek G, Bockenstedt L, Fish D, Dumler JS, Nadelman RB. The clinical assessment, treatment, and prevention of Lyme disease, human granulocytic anaplasmosis, and babesiosis: clinical practice guidelines by the Infectious Diseases Society of America. Clin Infect Dis. 2006:43:1089-134.

83. Pitzurra R, Steffen R, Tschopp A, Mutsch M. Diarrhoea in a large prospective cohort of European travellers to resource-limited destinations. BMC Infect Dis. 2010;10:231.

84. Monsel G, Caumes E. What's New in Travel-Associated Dermatology? J Travel Med. 2015;22:221-4.

85. Uysal HK, Akgul O, Aliyev $E_{1}$ Tunc M, Oner $Y$. A rare case of urinary schistosomiasis in Turkey. Travel Med Infect Dis. 2014;12:283-5.

86. O'Brien BM. A practical approach to common skin problems in returning travellers. Travel Med Infect Dis. 2009;7:125-46.

87. Leder K, Sundararajan V, Weld L, Pandey P, Brown G, Torresi J; GeoSentinel Surveillance Groupa. Respiratory tract infections in travelers: a review of the GeoSentinel surveillance network. Clin Infect Dis. 2003;36:399-406.

88. Kocazeybek BS, Yuksel P, Keskin D, Sheikh S, Habip Z, Yavuzer SS, Caliskan R, Altun YM, Kuskucu M, Cengiz M, Dinc HO, Karakullukcu A, Ergin S, Saribas S, Yilmaz N, Tokman HB. Travel-associated infections caused by unusual serogroups of Legionella pneumophila identified using Legionella BIOCHIP slides in Turkey and Iraq. Travel Med Infect Dis. 2016;14:248-54.

89. World Health Organization (WHO). Middle East respiratory syndrome coronavirus (MERS-CoV) - Saudi Arabia. Available from: http://www.who. int/csr/don/23-march-2016-mers-saudi-arabia/en/ 